\title{
Ideas reversibles, dibujos irreversibles. El tiempo como conector, en el dibujo de arquitectura, entre la mano que dibuja y el ojo que lee
}

\author{
Pablo Jeremías Juan Gutiérrez
}

\section{Abstract}

El dibujo de arquitectura, en tanto que parte de un medio de comunicación [Sainz 1990, p. 26], puede ser entendido como el significante que contiene o remite a una serie de imágenes e ideas que le sirven de referente y que han sido, en cualquier caso, organizadas por el autor del mismo. Esta relación no será por definición unívoca sino que, aunque siguiendo diferentes grados de ambigüedad, deberá construirse, de nuevo y cada vez, para cada lector. La interpretación de dicho significante, que marcará la manera en la que lo veremos [Wittgenstein 1958], supondrá un ejercicio mental imprescindible durante el análisis de lo gráfico y estará directamente relacionado con el proceso del dibujar que se haya llevado a cabo y que, en cualquier caso, siempre requiere de la temporalidad.

El presente trabajo de investigación parte de la hipótesis de que el lector debe realizar un ejercicio casi tan importante como el autor durante un proceso que, como tal, implica al tiempo y, además, requiere de la reversibilidad para su consecución. Partiendo de dicha idea se analiza la relación (y, por tanto, la distancia existente) entre el ojo que lee y la mano que dibuja. El planteamiento teórico se acompaña de ejemplos prácticos mediante los que ayudar a comprender el método desarrollado, fundamentado en la reversibilidad como herramienta de construcción de la imagen gráfica. Es dicho viaje "al revés" [Klee 1976, p. 60] mediante el que somos capaces de terminar analizando, poniendo en valor y, en definitiva, construyendo el criterio gráfico con el que evaluar el dibujo de arquitectura.

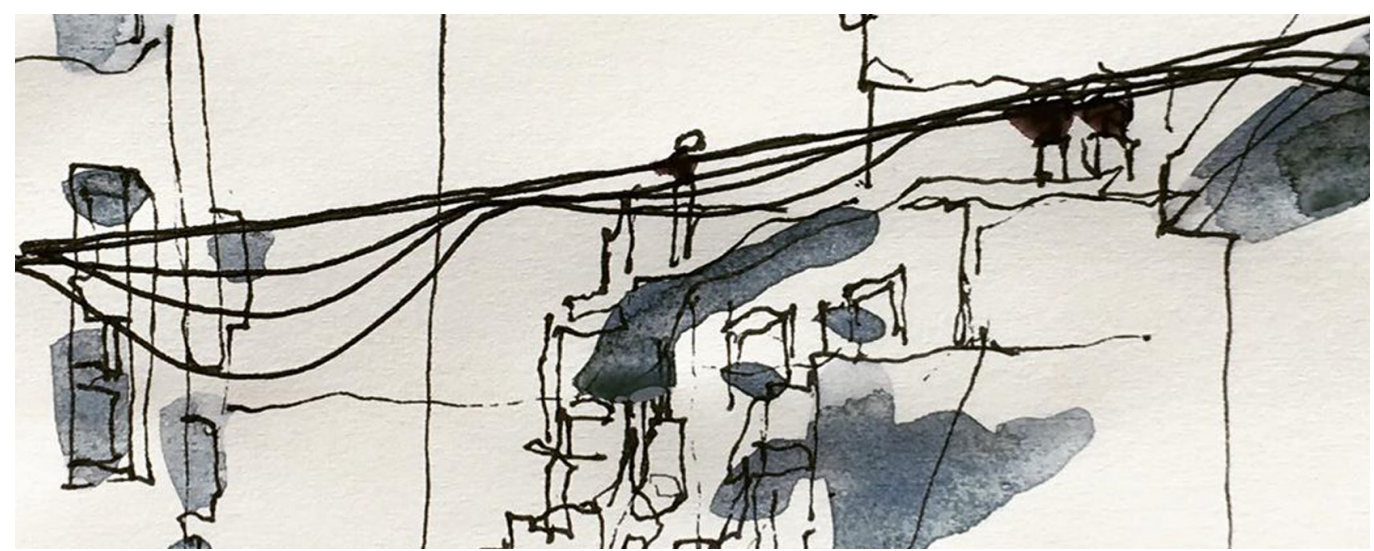




\section{Introducción}

El dibujo de arquitectura, en tanto que parte de un medio de comunicación [Sainz 1990, p. 26], puede ser entendido como el significante que contiene o remite a una serie de imágenes e ideas que le sirven de referente y que han sido, en cualquier caso, organizadas por el autor del mismo. Esta relación no será por definición unívoca sino que, aunque siguiendo diferentes grados de ambigüedad, deberá construirse, de nuevo y cada vez, para cada lector. La interpretación de dicho significante, que marcará la manera en la que lo veremos [Wittgenstein 1958], supondrá un ejercicio mental imprescindible durante el análisis de lo gráfico y estará directamente relacionado con el proceso del dibujar que se haya llevado a cabo y que, en cualquier caso, siempre requiere de la temporalidad.

El presente trabajo de investigación parte de la hipótesis de que el lector debe realizar un ejercicio casi tan importante como el autor durante un proceso que, como tal, implica al tiempo y, además, requiere de la reversibilidad para su consecución. Partiendo de dicha idea se analiza la relación ( $y$, por tanto, la distancia existente) entre el ojo que lee y la mano que dibuja. El conector entre ambos extremos del proceso del dibujar (la mano y el ojo) se evidencia de naturaleza temporal... es decir, será el tiempo entendido como contexto pero, también, como mecanismo de trabajo el que ayudará a entender la manera en la que el dibujo se entiende, por un lado, y se crea, por otro.

El planteamiento teórico se acompaña de ejemplos prácticos mediante los que ayudar a comprender el método desarrollado, fundamentado en la reversibilidad como herramienta de construcción de la imagen gráfica. Es dicho viaje "al revés" [Klee 1976, p. 60] mediante el que somos capaces de terminar analizando, poniendo en valor $y$, en definitiva, construyendo el criterio gráfico con el que evaluar el dibujo de arquitectura. Las conclusiones de la investigación sirven para argumentar el imprescindible papel que la visión temporal juega en el contexto gráfico al servir de nexo de unión entre el autor y el lector y, a la vez, anunciar una de las características más importantes (y desapercibidas) que las imágenes consecuencian: la anacronía [Didi-Huberman 2000].

\section{Objetivos}

Las líneas de trabajo que se desarrollan se corresponden, fundamentalmente, con los dos sentidos de una misma dirección; aquel que tiene que ver con el dibujo de arquitectura propiamente dicho entendido como proceso y el que, por su parte, ahonda en el concepto temporal aplicado a la lectura del dibujo. Las hipótesis de partida de la investigación son las siguientes:

- La distancia que existe entre el ojo que lee la grafía y la mano que la crea tiene carácter temporal. $\bigcirc$ dicho de otro modo: el tiempo es el conector principal entre el ojo que lee y la mano que dibuja.

- El proceso de dibujar es, a priori, lineal e irreversible. Por su parte, el proceso de leer el dibujo convoca la reversibilidad como parte de su naturaleza e, inevitablemente, introduce la anacronía en la imagen resultado.

- El objetivo del trabajo es el de, partiendo de las ideas arriba expuestas, desarrollar una metodología de investigación personal que permita, contando con el factor temporal, explicar los mecanismos de evaluación del dibujo desde la asimetría que, como explicaremos, se deriva de su proceso de creación-contemplación. Al chequeo de la hipótesis se sumará, como decimos, la inauguración de nuestra personal forma de entender la lectura de lo gráfico que, basándose en una crítica fundamentada en la importancia de la inevitable anacronía, nos permitirá esbozar las conclusiones que, como siempre, supondrán, también y en parte, el comienzo de nuevas investigaciones. 


\section{Metodología}

La mano que piensa (irreversiblemente)

Pensar el dibujo desde el punto de vista del final de un proceso de creación nos remite, intensamente, a las intenciones del dibujante. Será este quien tendrá las claves para su valoración ya que, tras el trazado de cada línea o la incorporación de cada mancha de color, realizará el ejercicio de sincronización entre la idea o ideas que intenta transmitir y los significantes gráficos con los que propone identificarlas. Durante estas acciones parece acertado identificar la destreza del dibujante como una de las herramientas protagonistas de un ejercicio que finaliza con una determinada grafía. Pero, siguiendo el hilo de nuestro discurso, debemos subrayar la condición de acción y de proceso que tiene un dibujo en general. Las palabras de Klee nos lo recuerdan cuando, en su libro Teoría del arte moderno escribe:" ¿Alguna vez nace un cuadro de modo súbito? ¡Nunca! Va montándose pieza a pieza, de no distinta manera, por cierto, que una casa" [Klee 1976, p. 58].

Tenemos, por tanto, junto a la certeza de que el dibujo 'aparece' poco a poco y consecutivamente, línea a línea, mancha a mancha, capa a capa, la condición de estar creándose cronológicamente, es decir, siguiendo el orden temporal que impone el devenir de nuestro ser-en-el-mundo [Heidegger 1975]. Este hecho, en apariencia inocente, nos lleva a considerar que un dibujo es, tal y como fue definida la condición temporal con posterioridad a Newton (por, por ejemplo, Prigogine), de condición irreversible... es decir, su conformación no tiene vuelta atrás ya que, incluso la goma de borrar o la pintura superpuesta (fig. I), dejará un trazo invisible en el soporte y, lo que es más importante, ocupará un espacio de tiempo en la duración de su creación.

Fig. I. Fragmento de David vencedor de Goliat ( I596) realizado por Caravaggio (I57|-1610) Izquierda: Fragmento original de la pintura, tal y como puede leerse actualmente. Derecha: radiografía realizada por Mina Gregori, en la que se observa una primera versión de la cabeza de versión de la cabeza de Contro: superposición. Procedencia:Wikipedia.

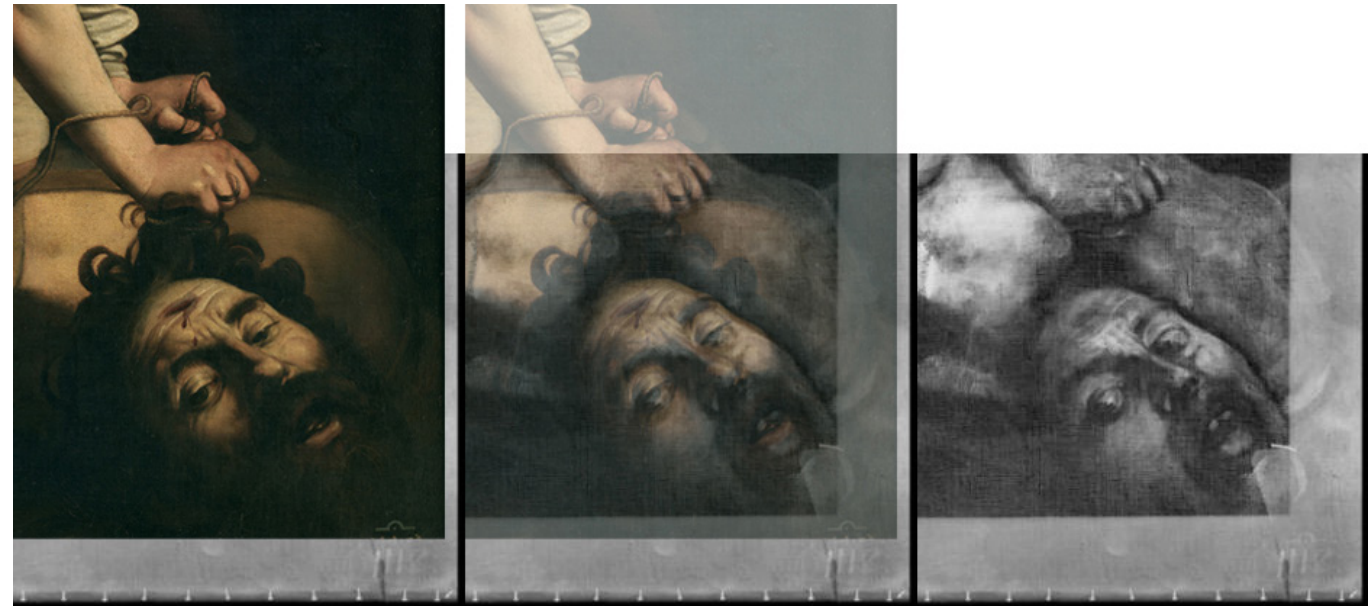

El ojo (que redibuja)

Parece sensato pensar que la existencia del dibujo no tiene sentido sin el lector que lo contempla. Incluso podemos entender al propio autor del mismo como lector ya que, aunque las intenciones del mismo acaben en un análisis privado, de alguna manera el dibujante tiene por definición un rol compartido (autor-lector). De esta manera, y centrándonos en el análisis de la obra cuando esta ha finalizado, podemos sintetizar que el sentido de la vista -título de la exquisita colección de ensayos del pensador John Berger [Berger 2006]es el principal medio para acceder al análisis de las pinturas en general y los dibujos de arquitectura en particular. Será a través del ojo que exploramos el lienzo y empezamos a recorrerlo como quien construye su historia y, aunque a través de éste, otros sentidos serán puestos en juego. Tal y como nos recuerda Juhani Pallasmaa: "creo que las sensaciones del tacto, la temperatura, el peso, la humedad, el olor y el movimiento en las imágenes visuales son tan reales como la propia percepción visual" [Pallasmaa 20 I I, p. 236]. 
El rol del espectador, pensador o crítico del dibujo sucede, en la mayoría de las ocasiones, ante la vista de un resultado concreto y específico, particular. De esta manera, tal y como nos recuerda Paul Klee, deberemos aprender a construir un recorrido revertido: "La principal desventaja de quien la contempla o reproduce consiste en que se ve súbitamente puesto delante de un resultado y en que sólo al revés puede recorrer la génesis de la obra" [Klee 1976 p. 60]. Pero, aunque muchos son los autores que coinciden en este punto "survey is like the reverse elaboration of a project and that performing a survey is like reading the history of a building backwards" [Cundari 20 16, p. 94], lo que nos interesa subrayar ahora es el papel activo del lector, y la importancia de la narración particular que termine componiendo ya que será, dicha construcción-narración, diferente para cada uno de los espectadores. El conjunto final, por lo tanto, será revelado como una consecuencia de una particular forma de entender, componer y relacionar las partes (fig. 2), ya que "también en el espectador la actividad principal es temporal" [Klee 1976, p. 60].

Fig. 2. Fading Away ( 1858 ) Composición fotográfica de Henry Peach Robinson (I830-190I). El pintor prerrafaelista realiza el primer fotomontaje de la historia, es decir, la primera propuesta fotográfica en la que distintos tiempos se pueden leer (dependiendo pueden leer (dependiendc simután dencia:Wikipedia.

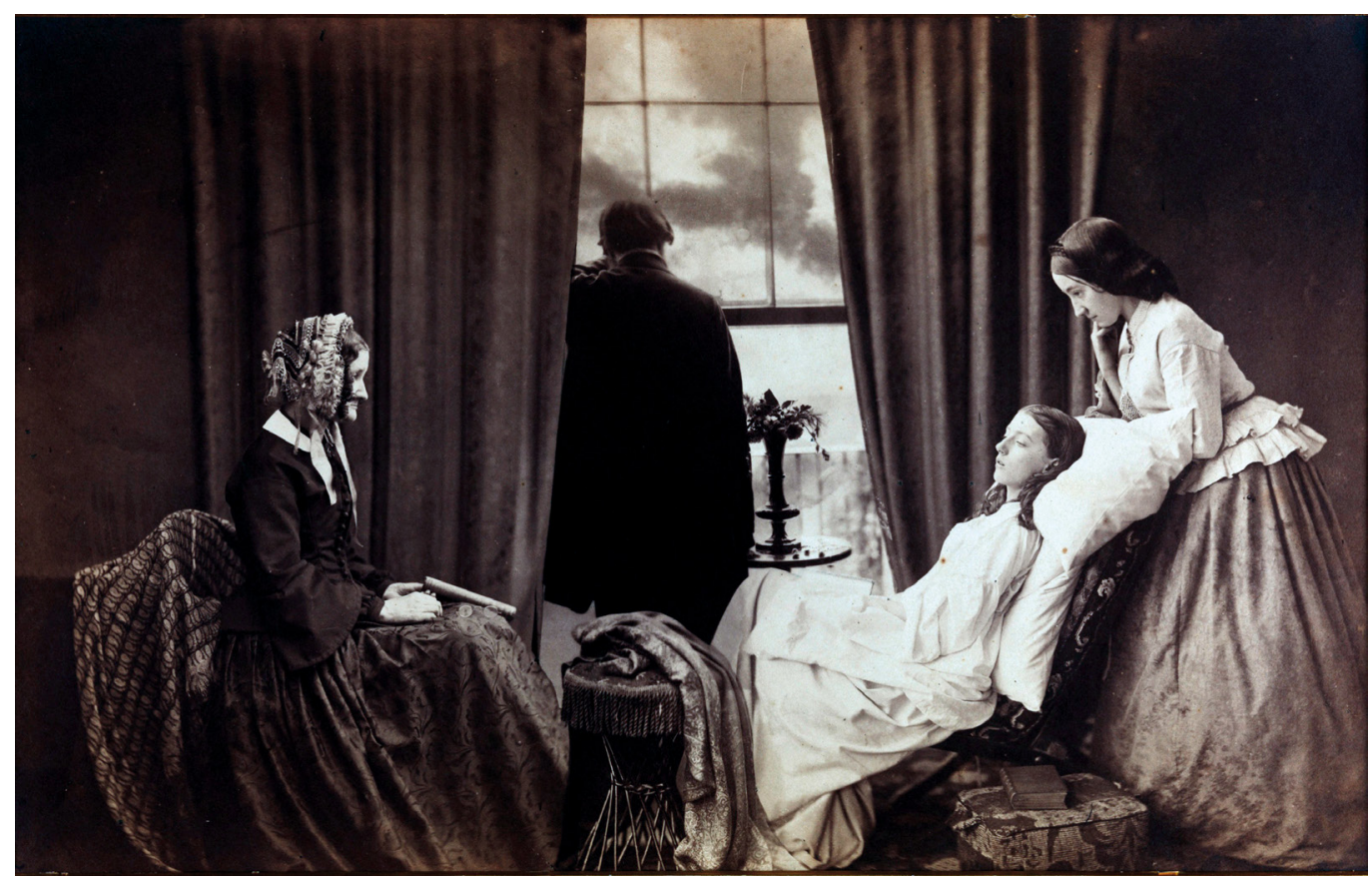

Anacronía (o la distancia temporal)

"Siempre, ante una imagen, estamos ante el tiempo [...] ¿cómo estar a la altura de todos los tiempos que esta imagen, ante nosotros, conjuga sobre tantos planos?" [Didi-Huberman 2000, p. 32]. Las palabras del pensador Did-Huberbam se nos presentan especialmente relevantes en este punto de la investigación en el que, de alguna manera, nos vemos comprometidos a establecer la relación y el tipo de conexión entre la mano que dibuja y el ojo que ve. Ambos son partes de un proceso en el que se inscribe todo dibujo y que compromete un posicionamiento, también, temporal: irreversible, rotundo y general, cuando se trata del hecho de creación, y reversible y particular, aunque concluyente, cuando se trata del razonamiento del que nos servimos para analizar y valorar.

En el caso del dibujo de una ciudad no es diferente: tal y como anunciábamos, las lecturas son, siempre y sin excepción, múltiples (fig. 3).Y amplias las posibilidades de reconocimiento e identificación. La anacronía (esa ambigüedad en clave temporal) está presente durante la lectura y el estudio, el análisis, de la grafía del territorio. No sólo porque el propio hecho urbano escapa de una definición cerrada o autista a la complejidad, identificándose más con 
un conjunto de parámetros, acciones y hechos, sino porque "no hay una herramienta gráfica que pueda dar una percepción real de esa interacción de factores" [Carazo 20 I 6, p. 34]. La desconexión entre lo representado (arquitectura y/o ciudad) y su representación (dibujo) será inevitable: la hermenéutica juega, por lo tanto, un papel importante durante el recorrido de la distancia temporal entre la mano que dibuja y el ojo que lee.Y en este punto la anacronía se torna en protagonista. Determinadas cuestiones, en el centro del debate de lo que la arquitectura significa, escaparán a la representación y, por tanto, la única forma de relacionarlas será mediante un desarrollo gráfico que sugiera (más que represente) o que señale (más que identifique). Cuando Robert Smithson habla de la imposibilidad de describir o registrar parte de la realidad arquitectónica [entendida como capacidad] está, precisamente, ahondando en los límites del dibujo, de la representación y, por tanto, en el territorio de la interpretación de la misma: "We are thinking of architecture's capacity [...] a capacity we can feel and act upon, but cannot necessarily describe or record" [Smithson 1992, p. 5].

Fig. 3. Rotating house (1921). Paul Klee (1879en el que el tector puede, en el cue elor puede dela mano (y gracias) al gran artista, componer su yrimat) y original) del hecho urbano. Procedencia Museo ThyssenBornemisza.

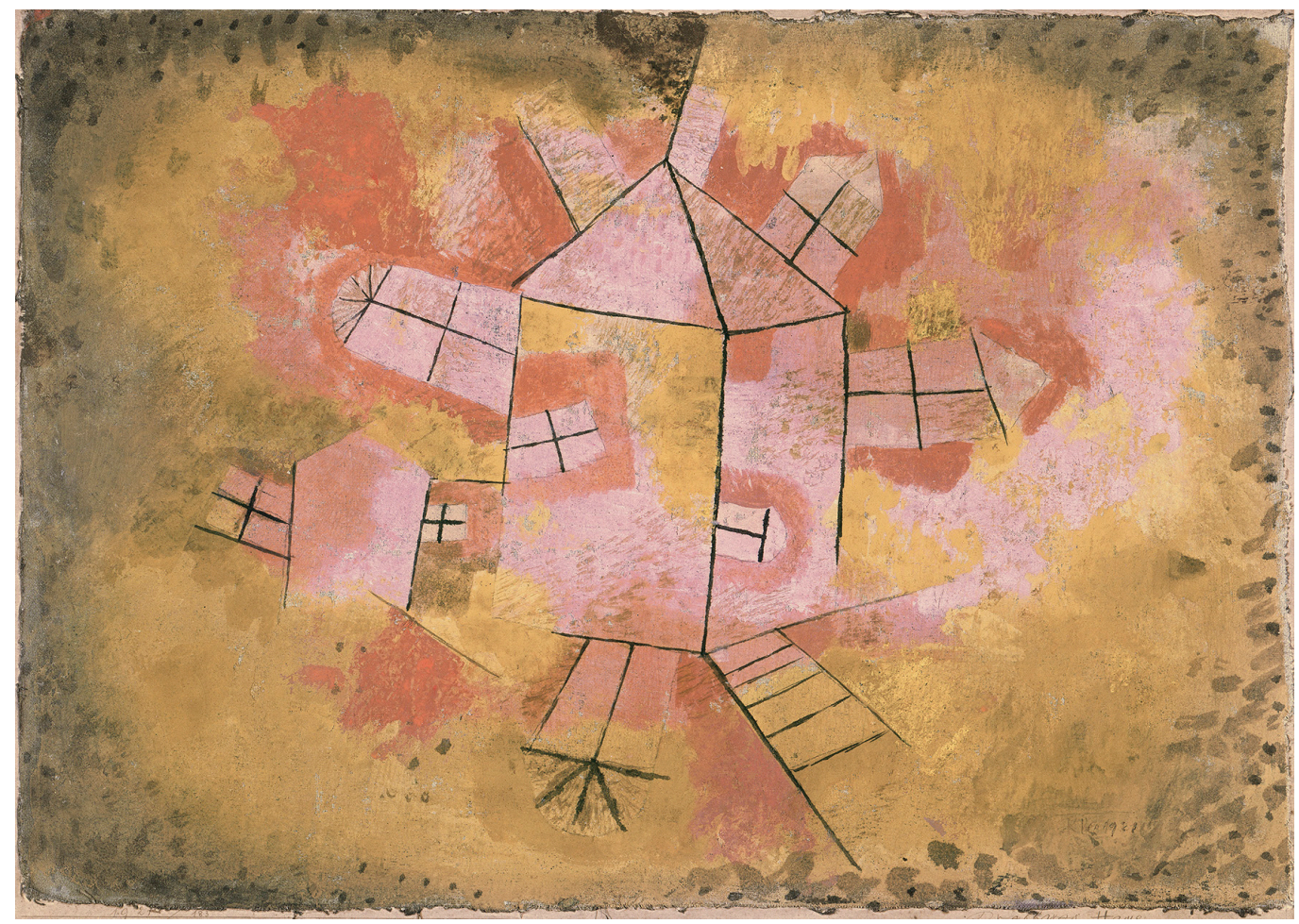

\section{Resultados}

"La obra de arte nace del movimiento, ella misma es movimiento fijado y se percibe en el movimiento." [Klee 1976, p. 60] Con esta (aparentemente) inocente frase Paul Klee introduce la problemática de lo temporal como parte inseparable los dos elementos sobre los que hemos trazado la línea de conexión. "Nace del movimiento" (la mano) y "se percibe en el movimiento (el ojo), La conexión, además, se realiza a partir del dibujo que es "movimiento fijado", es decir, tiempo grafiado. Incluso el elemento primero y más sintético de lo gráfico es entendido por los grandes pensadores como algo más que espacio material: "El punto es la mínima forma temporal" [Kandinsky 1952, p. 33]. La asimetría que comentábamos al principio de nuestro análisis se fundamenta en el hecho de que la mano que crea el dibujo está, de alguna manera, proponiendo irreversiblemente un dibujo, mientras que el ojo que lee y construye la imagen a partir de éste tiene un papel menos concluyente y no deja rastro material en sí mismo tal y como sí hace la mano. Lo llamamos reversible ya que debe intentar entender y 
desgranar, decodificar, las ideas tras el dibujo comenzando por el final y, además, puede moverse a voluntad por el lienzo, recomenzando en cada línea, en cada mancha, en cada color. Los resultados del trabajo se presentan como una metodología para entender y evaluar los dibujos de arquitectura en los que la consciencia de la anacronía [siguiendo la estela de Didi-Huberman] debe ocupar un lugar principal. No sólo en un contexto docente (que también) sino en un entorno de reflexión acerca del significado que nos proponen los autores con sus obras, en general. De la misma manera que la división del segundo con el trabajo de Eadweard Muybridge puede ser relacionada con la importancia y alcance de la división del átomo [Solnit 2004, p.7], la importancia de Didi-Huberman de asumir la anacronía como parte inherente de las imágenes puede ser el argumento más evidente que la pertinencia de un estudio de la conexión mano-ojo en clave temporal puede tener para el análisis de lo gráfico en un entorno arquitectónico en el que, a priori y tal y como hemos desarrollado, podríamos dejarla al margen.

Esta herramienta de análisis, aplicada durante el estudio de los dibujos, nos sirve para entender y ser capaces de relacionar más ideas de las propuestas por los autores en sus obras y, también, ser conscientes de la ambigüedad omnipresente y, por tanto, de la relatividad de nuestras suposiciones. David Hockney, ejemplo paradigmático, se encuentra actualmente inmerso en la relación entre la pintura tradicional y estudio de la fotografía junto con las técnicas digitales de dibujo. Leer sus cuadros significa realizar ejercicios reversibles mediante los que hacer relevante el torrente de ideas que el pintor nos propone. En palabras de OscarTusquets "estas obras no pretenden representar un instante sino la permanencia" [Tusquets 2019, p. 75]. Nuestro ojo, recorriendo el lienzo (por ejemplo de la fig.4), va construyendo los significados que, gracias al artista, componen el discurso. Una habitación, dentro de lo que parece ser un museo, dibujada desde una posición elevada. Tres hileras de sillas, habitadas por una serie de personas, se disponen frente a un gran espejo horizontal que, fiel a las leyes de la reflexión, reproduce lo que tiene enfrente. Nuestro ojo, como decimos, recorre el lienzo. El espejo puede leerse, en realidad, como un cuadro dentro del cuadro que contemplamos en el que no podemos dejar de pensar qué ocurriría si pudiera reflejarnos. Pero sucede, por encima de todo, algo muy extraño a primera vista: hay personas que están repetidas, en distintos lugares y realizando distintas acciones. Lo cual nos hace entender el conjunto como una doble anacronía (la propia de la imagen y la creada por el pintor). Nuestra mirada parece flotar, elevarse, tras comprender el juego temporal propuesto por el autor y la reflexión implícita: la pintura como extensión de un territorio capaz de significar a la realidad $y$, a la vez, introducir la libertad temporal (y, por eso, reversible) ausente en el mundo en devenir en el que habitamos.

Fig. 4. David Hockney, Pictured Gathering with Mirror, 2018 (Ollman 2019).

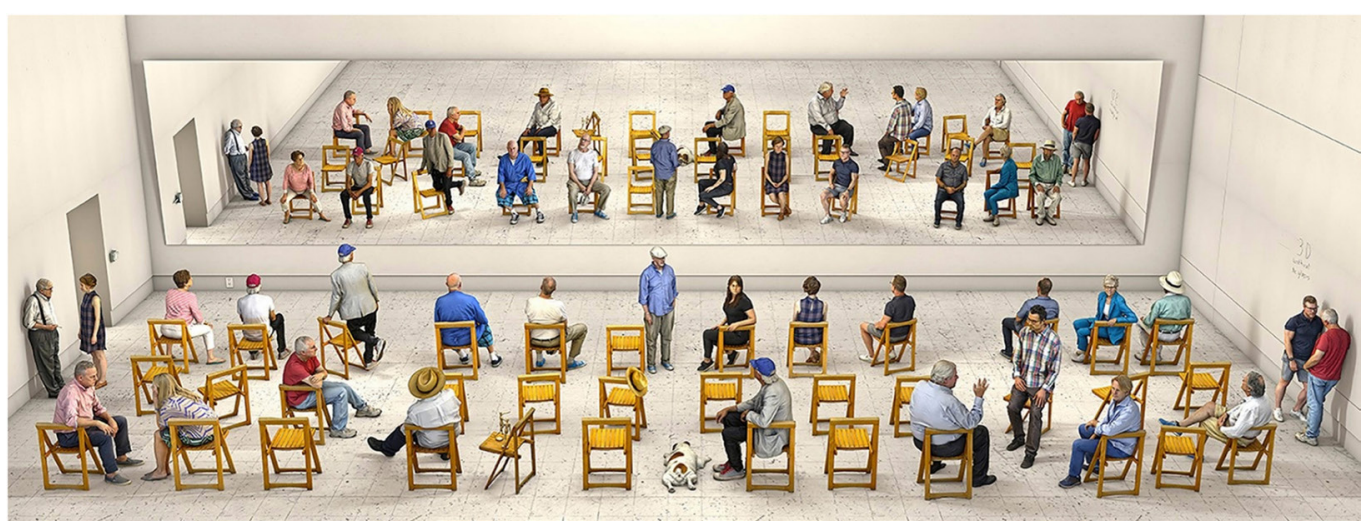

A modo de ejemplo de aplicación de la teoría, se reproducen a continuación dos series de imágenes en las que observamos resultados del trabajo en un medio gráfico tras la asunción de las principales hipótesis desarrolladas, en concreto la que evidencia al ojo como elemento transformador (y re-transformador, en tanto en cuanto que reversible) de la imagen que 
Fig. 5. a) Superposición de puertas codificadas del centro de Alicante, estub) Thea de tiempo orritzar la información Patolópez Leivay Pablo López Leiva y c) manez Yañ c) mapeado de un cecorrido programado Taverner Ĺćcrilermo Esteve Díez. diantes: Raúl Diaz Valera e Innacio López Aniorte como herramienta para
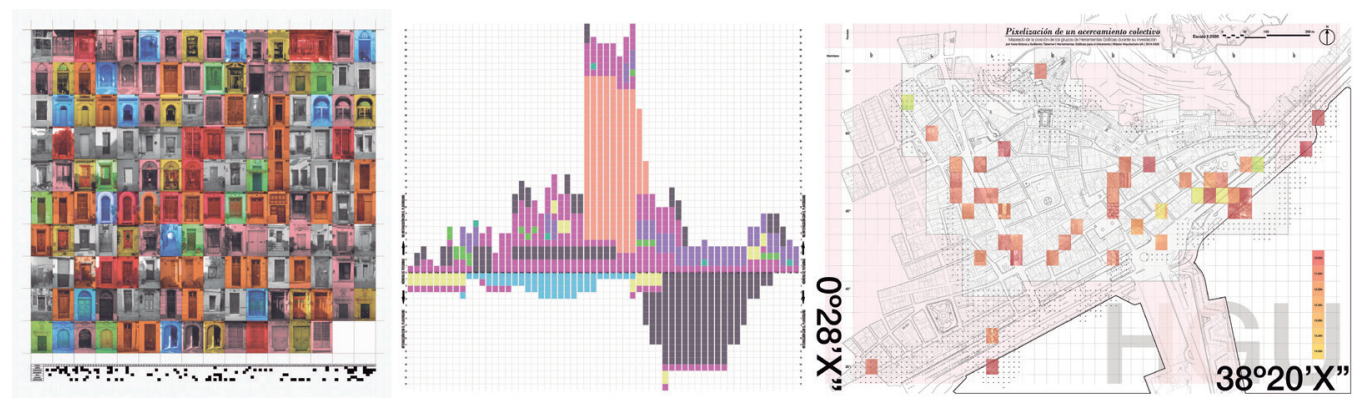

Fig. 6. a) Dibujando las historias dentro de una casa, estudiante: Raúl Díaz Valera; b) superposición de acciones, estudiantes: Jesús Gómez Martínez e dibujo como herramienta para representar mienta para representar la duración, estudiante: Jose Manuel Nolasco

se mira. Los alumnos del Máster de Arquitectura de la universidad de Alicante generan, así, sus propios significantes gráficos que tienen que ver con la ciudad y que se posicionan, conscientemente, frente a la multiplicidad de miradas y lecturas que albergan.
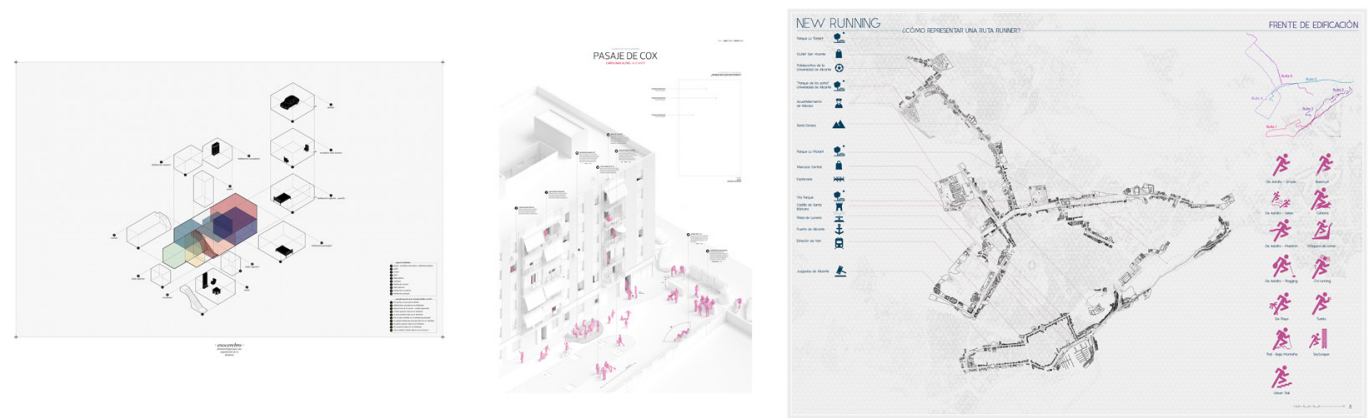

\section{Conclusiones}

Las conclusiones, final de la presente experiencia y comienzo de las siguientes, se pueden sintetizar de la siguiente manera:

- Al definir como temporal la distancia entre el ojo que lee y la mano que dibuja situamos al lector en una posición necesariamente activa (al entender el significado del dibujo como el resultado de un posicionamiento, también, respecto a la anacronía que propone).

- La reversibilidad durante la lectura es la característica principal que permite que las [re] consideraciones propias acerca de lo gráfico se sincronicen con las propuestas por los grandes pensadores y críticos.

- La irreversibilidad (durante el proceso de construcción de los significantes que conforman el dibujo) requiere que cada grafía se entienda como un esfuerzo independiente de codificar una serie de ideas y prepararlas para un viaje temporal que, en la mayoría de las ocasiones, nos sobrevive o nos es ajeno pero que, siempre, comienza con nuestra labor de dibujar.

\section{Reconocimiento}

El presente trabajo se desarrolla como parte de un proyecto I+D+I titulado "La representación del tiempo en la expresión gráfica", con referencia proyecto-emergente-GREI8-10 y financiado, en pública concurrencia, por el Vicerrectorado de Investigación y Transferencia de Conocimiento de la Universidad de Alicante. 


\section{Referencias}

Carazo Eduardo (2016). The role of the drawing in the research and interpretation of urban form. In Chías Pilar, Cardone Vito (eds). Drawing and Architecture 1986-20 16, Thirty Years of Research. Alcalà de Henares: Servicio de publicationes de la Universidad de Alcalá, pp. 32-45.

Cundari Cesare (2016). Architectural survey as a merged interdisciplinary activity. In Chías Pilar, Cardone Vito (eds). Drawing and Architecture 1986-20 16, Thirty Years of Research. Alcalà de Henares: Servicio de publicationes de la Universidad de Alcalá, pp. 90- 103.

Didi-Huberman Georges (2000). Before Time. Buenos Aires: Adriana Hidalgo Editora.

Heidegger Martin (1975). Ser y tiempo. Madrid: Editorial Trotta.

Kandinsky Wassily (1952). Punto y línea sobre el plano. Contribución al análisis de los elementos pictóricos. Barcelona: Editorial Labor.

Klee Paul (1976). Teoría del arte moderno. Buenos Aires: Ediciones Caldén.

Ollman Leah (2019). Review: David Hockney's latest: 'photographic drawings' and delectable paintings. In Los Ángeles Times <https://www.latimes.com/entertainment/arts/la-et-cm-david-hockney-review-201903|4-story.html>.

Pallasmaa Juhani (20I I). Materia, hapticidad y tiempo. In Revista el Croquis, n I 58. Madrid.

Sainz Jorge (1990). El dibujo de arquitectura. Teoría e historia de un lenguaje gráfico. Madrid: Editorial Nerea.

Smithson Alison, Smithson Peter (1992). The charged void: urbanism. New York: The Monacelli Press.

Solnit Rebecca (2004). River of Shadows: Eadweard Muybridge and the Technological Wild West. New York: Penguin Books.

Tusquets Oscar (2019). Pasando a limpio. Barcelona: Acantilado.

Wittgenstein Ludwig (1999). Investigaciones filosóficas. Barcelona: Ediciones Altaya (I Ed. 1958. Philosophische untersuchungen, London: Basil Blackwell).

Autor

Pablo Jeremías Juan Gutiérrez, Universidad de Alicante, pablo.juan@gcloud.ua.es

Para citar este capítulo: Gutiérrez Pablo Jeremías Juan (2020). Ideas reversibles, dibujos irreversibles. El tiempo como conector, en el dibujo de arquitectura, entre la mano que dibuja y el ojo que lee/Reversible ideas, irreversible drawings. Time as a conector between the hand that draws and the eye that reads. In Arena A., Arena M., Brandolino R.G., Colistra D., Ginex G., Mediati D., Nucifora S., Raffa P. (a cura di). Connettere. Un disegno per annodare e tessere. Atti del $42^{\circ}$ Convegno Internazionale dei Docenti delle Discipline della Rappresentazione/Connecting. Drawing for weaving relationships. Proceedings of the 42th International Conference of Representation Disciplines Teachers. Milano: FrancoAngeli, pp. I 205- I 220. 


\section{Reversible Ideas, Irreversible Drawings. Time as a Connector between the Hand that Draws and the Eye that Reads}

Pablo Jeremías Juan Gutiérrez

\section{Abstract}

Architectural drawing, as part of a communication media [Sainz 1990, p. 26], can be understood as the signifier that contains or refers to a series of images and ideas that serve as a reference and have been, in any case, organized by its author. This relationship will not be by definition unambiguous but, although following different degrees of ambiguity, it must be constructed, again and every time, for each reader.The interpretation of this signifier, which will define the way in which we will see it [Wittgenstein 1958], will be an essential mental exercise during the analysis of the graphic and will be directly related to the drawing process that has been carried out and which, in In any case, it always requires temporality.

The current research work starts from the hypothesis that the reader must carry out an exercise almost as important as the author during a process that, as such, involves time and, in addition, requires reversibility for its achievement. Based on this idea, the relationship (and therefore the distance) between the eye that reads and the hand that draws is analyzed. The theoretical approach is accompanied by practical examples through which to help understand the developed method, based on reversibility as a construction tool for the graphic image. It is this trip 'backwards' [Klee 1976, p. 60] through which we are able to end by analyzing, highlighting and, ultimately, constructing the graphic criteria with which to evaluate the architectural drawing.

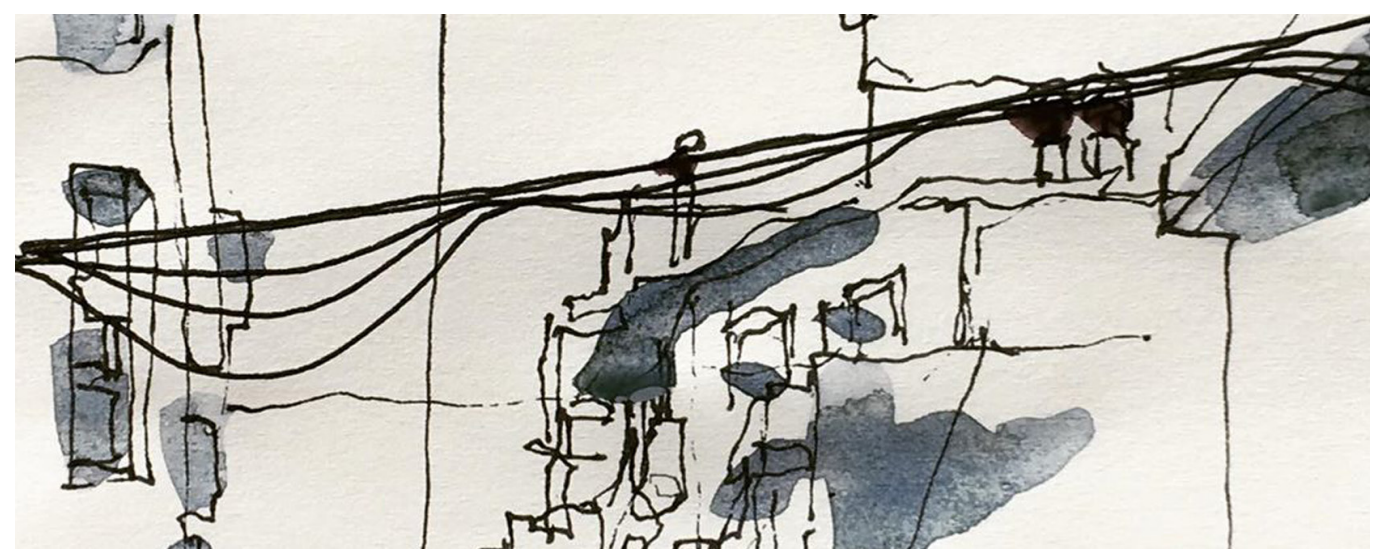




\section{Introduction}

Architectural drawing, as part of a communication media [Sainz 1990, p. 26], can be understood as the signifier that contains or refers to a series of images and ideas that serve as a reference and have been, in any case, organized by its author. This relationship will not be by definition unambiguous but, although following different degrees of ambiguity, it must be constructed, again and every time, for each reader. The interpretation of this signifier, which will define the way in which we will see it [Wittgenstein 1958], will be an essential mental exercise during the analysis of the graphic and will be directly related to the drawing process that has been carried out and which, in In any case, it always requires temporality.

The current research work starts from the hypothesis that the reader must carry out an exercise almost as important as the author during a process that, as such, involves time and, in addition, requires reversibility for its achievement. Based on this idea, the relationship (and therefore the distance) between the eye that reads and the hand that draws is analysed. The connector between both ends of the drawing process (the hand and the eye) is evident in a temporary nature... that is to say, it will be time (understood as a context but, also, as a working mechanism) that will help to understand the way in which the drawing is understood on the one hand and created on the other.

The theoretical approach is accompanied by practical examples through which to help to understand the developed method, based on reversibility as a construction tool for the graphic image. It is this trip 'backwards' [Klee 1976, p. 60] through which we are able to end by analyzing, highlighting and, ultimately, constructing the graphic criteria with which to evaluate the architectural drawing. The research conclusions serve to argue the essential role that temporal vision plays in the graphic context by serving as a link between the author and the reader and, at the same time, announcing one of the most important (and unnoticed) characteristic that is derived from the images: the anachronism [Didi-Huberman 2000].

\section{Goals}

The lines of investigation that are developed correspond, fundamentally, with the two posibilities within the same direction; the one that has to do with the architectural drawing itself understood as a process and, on the other hand, the one that delves into the temporal concept applied to the reading of the drawing. The starting hypotheses of the research are as follows:

- The distance, between the eye that reads the signifier and the hand that creates it, it is temporary. In other words: time is the main connector between the eye that reads and the hand that draws.

- The drawing process is, a priori, linear and irreversible. Meanwhile, the process of reading the drawing calls for reversibility as part of its nature and inevitably introduces anachronism in the final and resulting image.

- The aim of this study is to, based on the ideas set out above, develop a personal research methodology that allows, using the time factor, to explain the assessing mechanisms of the drawing from the asymmetry that, as we will explain, derives from its process of creation-contemplation. By checking the hypothesis, as we say, the inauguration of our personal way of understanding the reading of the graphic will be added: based on a criticism rooted on the importance of the inevitable anachronism, it will allow us to sketch the conclusions that, as always, will suppose, also and in part, the beginning of new researching lines. 


\section{Methodology}

The hand that thinks (irreversibly)

Thinking about drawing from the point of view of the end of a creation process refers us, intensely, to the draftsman's purposes. They will be the ones who will have the keys to their assessment since, after drawing each line or incorporating each color stain, they will carry out the synchronization exercise between the idea or ideas they are trying to convey and the graphic signifiers with which they propose to identify them. During these actions, it seems correct to identify the skill of the draftsman as one of the main tools of an exercise that ends in a certain way. But, following the thread of our discourse, we must underline the condition of action and process that any drawing, in general, has. Klee's words remind us of this when, in his book Theory of Modern Art, he writes: "Is a painting ever born suddenly? Never! It is being built piece by piece, no different, by the way, than a house" [Klee 1976, p. 58].

We have, therefore, together with the certainty that the drawing 'appears' little by little and consecutively, line by line, stain by stain, layer by layer, the condition of being created chronologically, that is, following the temporal order that the becoming of our being-in-the-world imposes [Heidegger]. This (apparently) innocent fact leads us to consider that a drawing is, in the same way that the temporal condition was defined after Newton (by, for example, Prigogine), an irreversible condition ... that is, its conformation has no turning back since, even the eraser or the overlay paint (fig. I), will leave an invisible trace on the support and, most importantly, it will occupy a space of time in the duration of its creation.

Fig. I. Fragment of David victor of Goliath (1596) made by Caravaggio (I57|-1610). Left: Original fragment of the painting, as it can currently be read. Right: X-ray taken by Mina Gregori, showing more expressive head. Center: overlay Origin: Center: overlay. Origin:
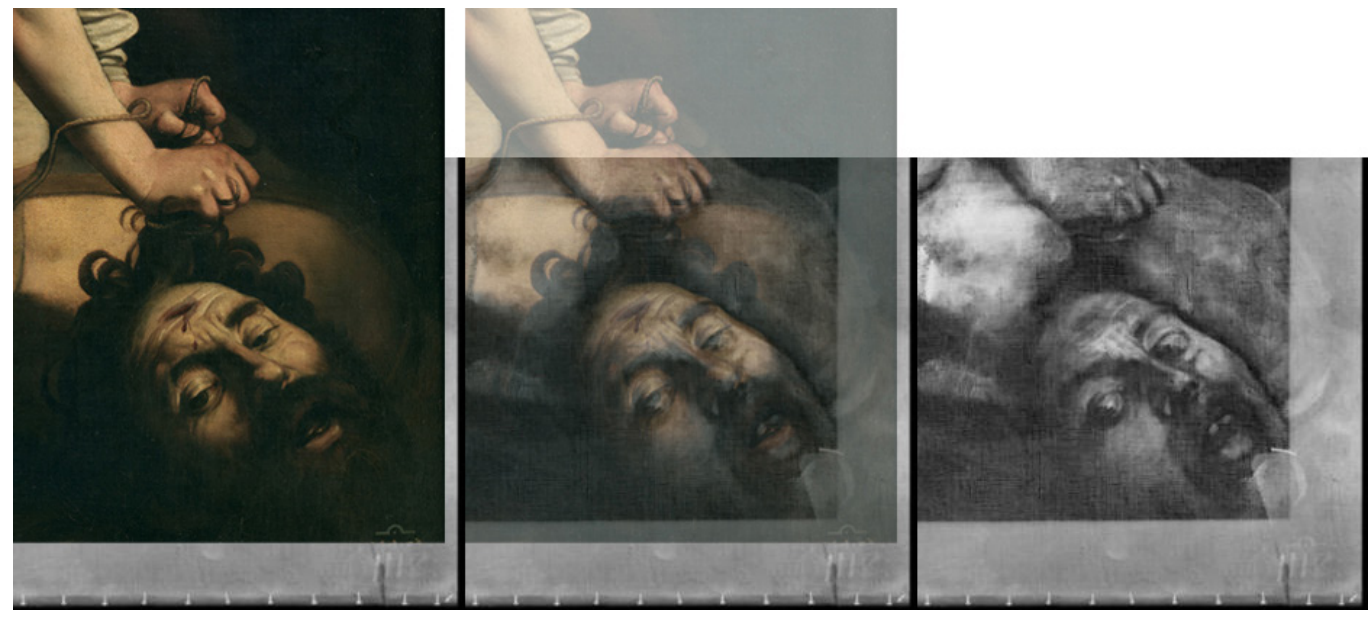

The eye (which redraws)

It seems sensible to think that the existence of the drawing is meaningless without the reader who contemplates it. We can even understand the author himself as a reader since, even if his/her intentions end in a private analysis, in some way the draftsman has by definition a shared role (author-reader). In this way, and focusing on the analysis of the work when it is finished, we can summarize that the sense of sight -the title of the exquisite collection of essays by the thinker John Berger [Berger 2006] - is the main means of accessing the analysis of paintings in general and architectural drawings in particular. It will be through the eye that we explore the canvas and begin to traverse it as one who builds its history and, although through it, other senses will be brought into play. As Juhani Pallasmaa reminds us: "I think that the sensations of touch, temperature, weight, humidity, smell and movement in visual images are as real as visual perception itself"' [Pallasmaa 20I I, p. 236]. 
The viewer (thinker or critic of the drawing) role happens, in most cases, in view of a concrete and specific, particular result. In this way, as Paul Klee reminds us, we must learn to construct a reversed path:"The main disadvantage of those who contemplate or reproduce it is that they are suddenly placed in front of a result and that only the other way around can they go through the genesis of the work" [Klee 1976, p. 60]. But, although many authors agree on this point, "Survey is like the reverse elaboration of a project and that performing a survey is like reading the history of a building backwards" [Cundari 20 I 6, p. 94], what we are interested in underlining now is the active role of the reader, and the importance of the particular narration that ends up composing since it will be, this construction-narration, different for each of the viewers. The final set, therefore, will be revealed as a consequence of a particular way of understanding, composing and relating the parts (fig. 2), since "the main activity is also temporary in the viewer" [Klee 1976, p. 60].

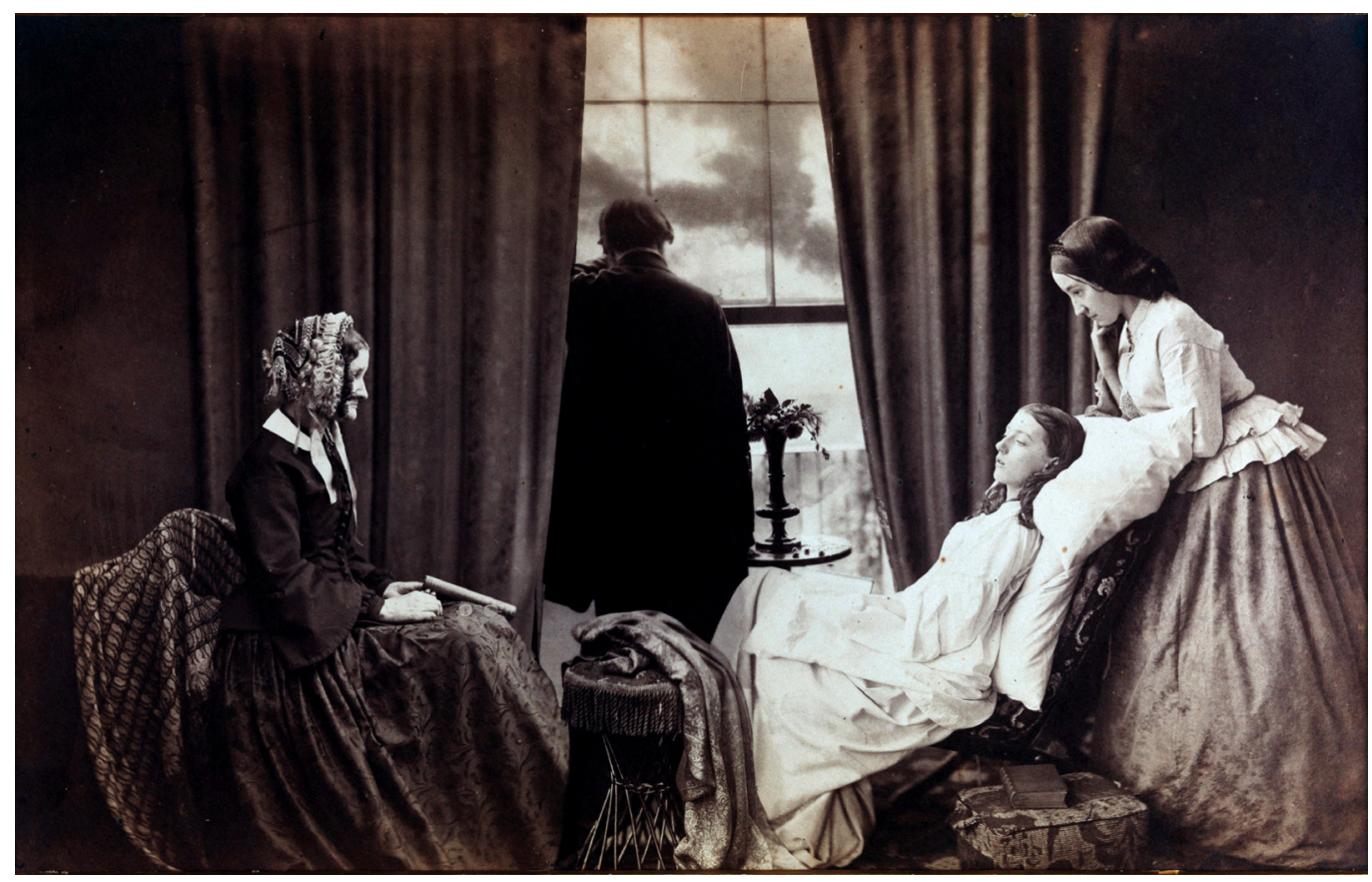

Anachrony (or the temporal distance)

"Always, before an image, we are before time [...] How can we live up to all the times that this image, before us, combines on so many planes?" [Didi-Huberman 2000, p. 32]. The words of the thinker Did-Huberbam appear especially relevant to us at this point in the research where, in some way, we are committed to establishing the relationship and the type of connection between the hand that draws and the eye that sees. Both are parts of a process in which every drawing is inscribed and that compromises a position, also, temporary: irreversible, resounding and general, when it comes to the fact of creation, and reversible and particular, although conclusive, when it comes to the reasoning that we use to analyze and assess.

The case of the drawing of a city it is not different: as we announced, the readings are, always and without exception, multiples (fig. 3). And wide the possibilities of recognition and identification. The anachronism (that ambiguity in temporal key) is present during the reading and study, analysis, of the drawing of the territory. Not only because the urban fact itself escapes from a closed or autistic definition to complexity, identifying itself more with a 
set of parameters, actions and facts, but also because "there is no graphic tool that can give a real perception of this interaction of factors" [Carazo 2016, p. 34].

The disconnection between what is represented (architecture and/or city) and its representation (drawing) will be inevitable: hermeneutics therefore plays an important role during the journey of the temporal distance between the hand that draws and the eye that reads. And at this point anachronism becomes the protagonist. Certain questions, at the center of the discussion on what architecture means, will escape representation and, therefore, the only way to relate them will be through a graphic development that suggests (rather than represents) or points to (more than identifies). When Robert Smithson speaks of the impossibility of describing or registering part of architectural reality (understood as capacity), he is precisely delving into the limits of drawing, representation and, therefore, in the territory of its interpretation: "We are thinking of architecture's capacity [...] a capacity we can feel and act upon, but cannot necessarily describe or record" [Smithson 1992, p. 5].

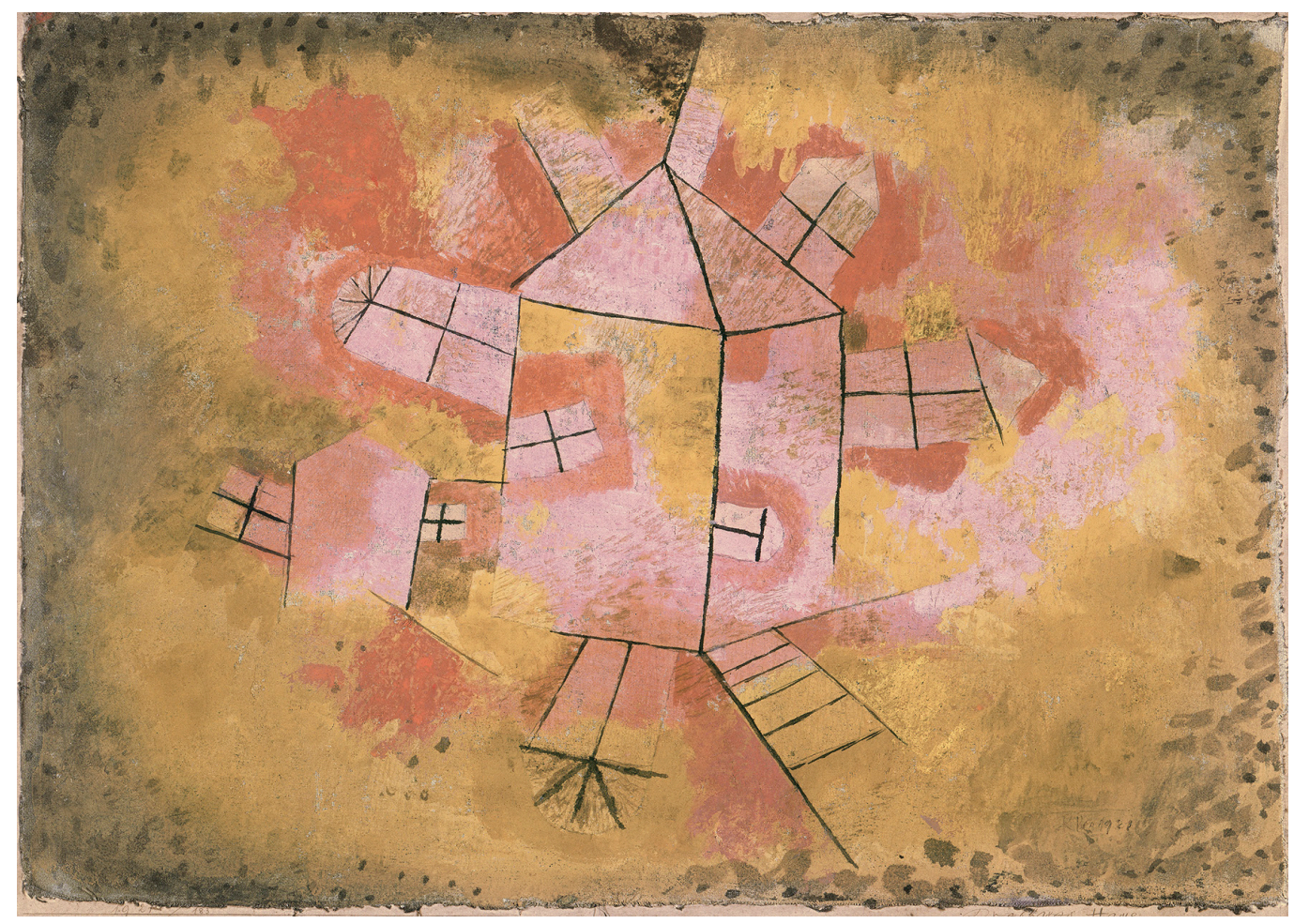

\section{Results}

"The work of art (masterpiece) is born from movement, it is itself fixed movement and is perceived in movement." [Klee 1976, p. 60] With this (apparently) innocent phrase Paul Klee introduces the problem of the temporal fact as an inseparable part of the two elements on which we have drawn the line of connection. "It is born of movement" (the hand) and "it is perceived in the movement" (the eye). The connection, in addition, is made from the drawing that is "fixed movement", that is, graphed time. Even the first and most synthetic element of the graphic is understood by the great thinkers as something more than material space: "The point is the minimal temporal form" [Kandinsky 1952, p.33]. The asymmetry that we commented at the beginning of our analysis is based on the fact that the hand that creates the drawing is, in some way, irreversibly proposing a drawing, while the eye that reads and builds the image from it has a role less conclusive and leaves no material trace in itself as the hand does. We call it reversible since you must try to understand and break down, 
decode, the ideas behind the drawing starting at the end and, in addition, you can move at will on the canvas, starting again in each line, in each stain, in each color.

The results of the work are presented as a methodology to understand and assess architectural drawings in which the consciousness of anachronism (following in the wake of Didi-Huberman) must occupy a main place. Not only in a teaching context (which also) but in an environment of reflection on the meaning that the authors propose to us with their works, in general. In the same way that the division of the second with the research of Eadweard Muybridge can be related to the importance and scope of the division of the atom [Solnit 2004, p. 7], the importance of Didi-Huberman to assume anachronism as an inherent part of the Images may be the most obvious argument that the relevance of a study of the hand-eye connection in temporal terms can have for the analysis of the graphic in an architectural environment in which, a priori and as we have developed, we could leave it to the margin.

This analysis tool, applied during the study of the drawings, helps us to understand and be able to relate more ideas than those proposed by the authors in their works and, also, to be aware of the omnipresent ambiguity and, therefore, of the relativity of our assumptions. David Hockney, a paradigmatic example, is currently immersed in the relationship between traditional painting and the study of photography along with digital drawing techniques. Reading his paintings means carrying out reversible exercises through which to make relevant the torrent of ideas that the painter proposes to us. In the words of OscarTusquets "these works are not intended to represent an instant but rather permanence" [Tusquets 2019, p. 75]. Our eye, traversing the canvas (for example in fig. 4), is constructing the meanings that, thanks to the artist, make up the discourse. A room, inside what appears to be a museum, drawn from an elevated position. Three rows of chairs, inhabited by a series of people, are arranged in front of a large horizontal mirror that, faithful to the laws of reflection, reproduces what is in front of it. Our eye, as we say, runs along the canvas. The mirror can actually be read as a painting within the painting that we contemplate, in which we cannot stop thinking about what would happen if it could reflect us. But above all, something very strange happens at first sight: there are people who are repeated, in different places and performing different actions. Which makes us understand the whole as a double anachronism (that of the image and that created by the painter). Our gaze seems to float, to rise, after understanding the temporal game proposed by the author and the implicit reflection: painting as an extension of a territory capable of signifying reality and, at the same time, introducing temporal freedom (and, therefore, reversible) absent in the becoming world in which we live.

Fig. 4. David Hockney, Pictured Gathering with Mirror, 2018 (Ollman 2019).

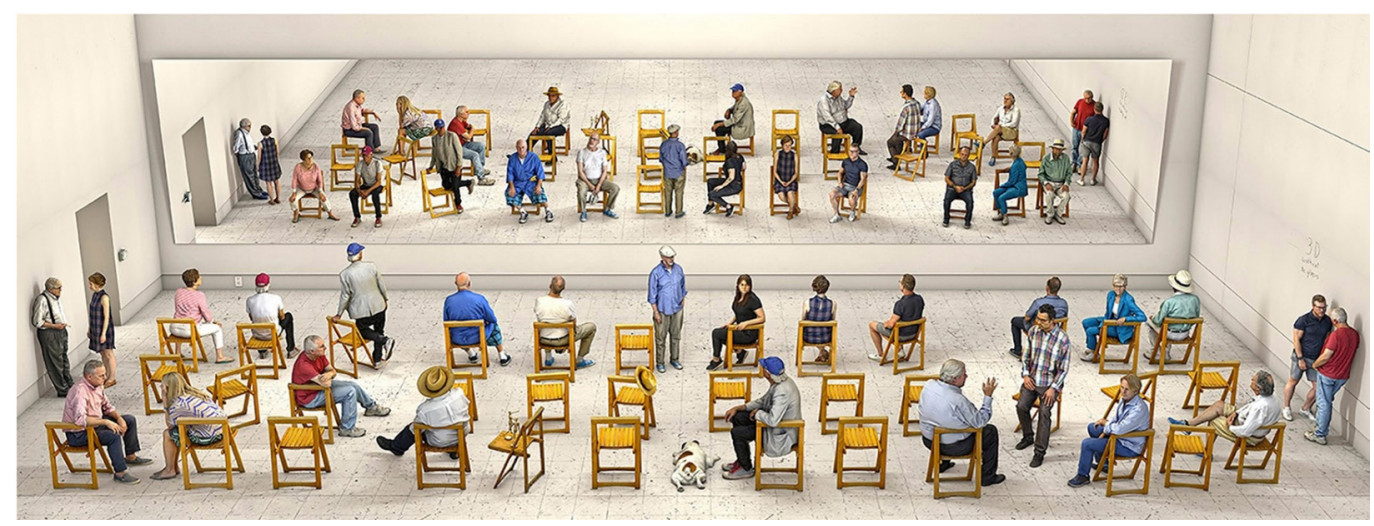

As an example of the application of the theory, two series of images are reproduced below in which we observe results of the work in a graphic medium after the assumption of the main hypotheses developed, specifically the one that shows the eye as a transforming element (and re-transformer, insofar as reversible) of the image being viewed. The students 
of the Master of Architecture at the University of Alicante, thus, generate their own graphic signifiers that have to do with the city and that position themselves, consciously, in the face of the multiplicity of glances and readings that they house.

Fig. 5. a) Overlapping of coded doors in the center of Alicante, students: Raul Díaz Valera and gnacio López Aniorte;
b) Timeline as a tool to organize territorial infororganize territorial infor López Leiva and Daniel López Yañez;

c) Mapping a scheduled tour, students: Guillermo Taverner Llácer and Irene Esteve Díez.
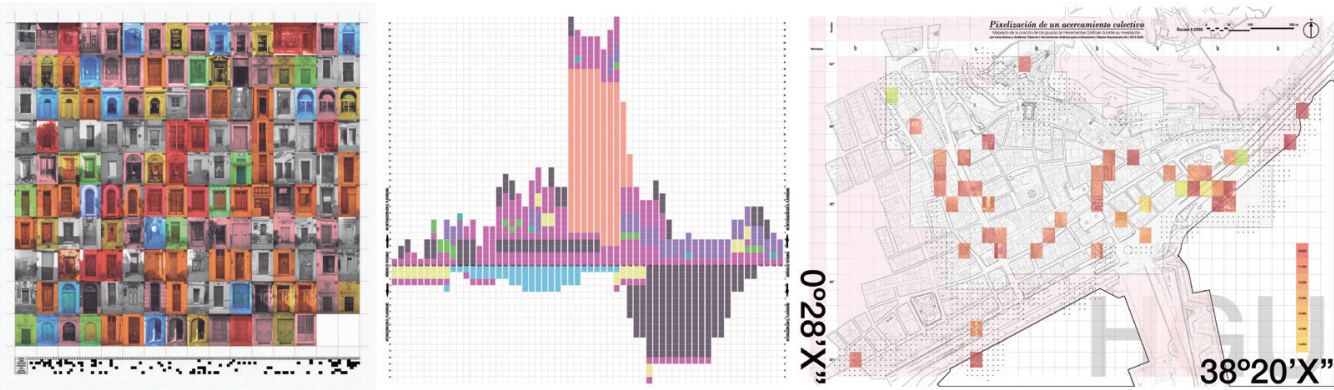

Fig. 6. a) Drawing the stories inside a house, student: Raúl Díaz Valera b) Overlapping actions, students: Jesús Gómez Martínez and Kevin Mar co Pacheco; c) Drawing as a tool to represent duration, student: Jose Manuel Nolasco Vidal.

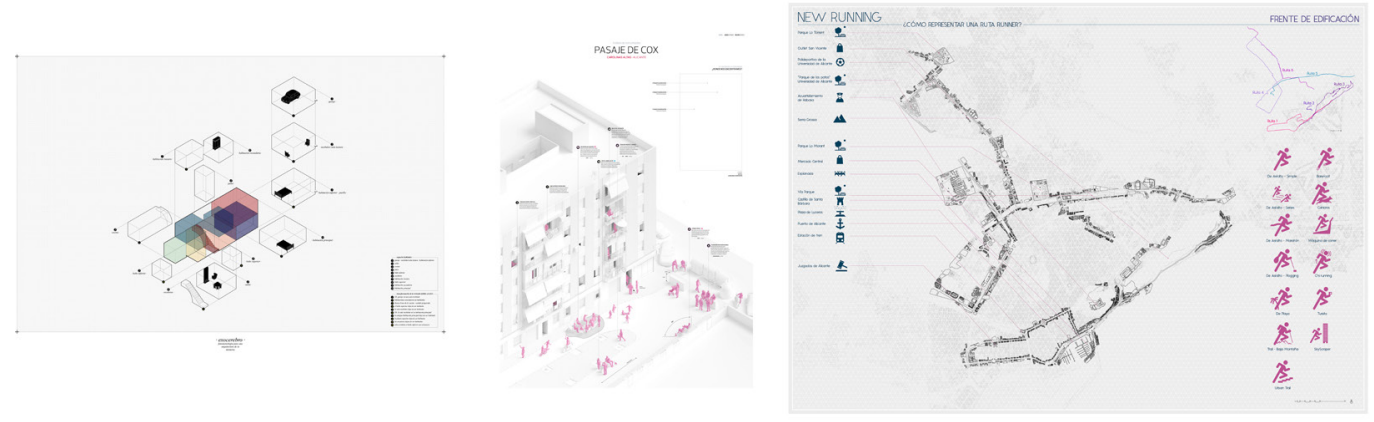

\section{Conclusions}

The conclusions, end of the present experience and beginning of the following ones, can be summarized as follows:

- By defining the distance between the eye that reads and the hand that draws as temporary, we place the reader in a necessarily active position (when understanding the meaning of the drawing as the result of a positioning, also, with respect to the anachronism it proposes); - Reversibility during reading is the main characteristic that allows the own (re) considerations about the graphic to be synchronized with those proposed by the great thinkers and critics;

- Irreversibility (during the process of building the signifiers that make up the drawing) requires that each element be understood as an independent effort to encode a series of ideas and prepare them for a temporary trip that, in most cases, survives us or it is alien to us but that always begins with our work of drawing.

\section{Acknowledgement}

This work is carried out as part of a R + D + I project entitled "The representation of time in graphic expression", with reference to the emerging-project-GREI8-10 and financed, in public attendance, by the Office of the Vicerrectorado de Investigación y Transferencia de Conocimiento of the University of Alicante 


\section{References}

Carazo Eduardo (2016). The role of the drawing in the research and interpretation of urban form. In Chías Pilar, Cardone Vito (eds). Drawing and Architecture 1986-20 16, Thirty Years of Research. Alcalà de Henares: Servicio de publicationes de la Universidad de Alcalá, pp. 32-45.

Cundari Cesare (2016). Architectural survey as a merged interdisciplinary activity. In Chías Pilar, Cardone Vito (eds). Drawing and Architecture 1986-20 16, Thirty Years of Research. Alcalà de Henares: Servicio de publicationes de la Universidad de Alcalá, pp. 90-103.

Didi-Huberman Georges (2000). Before Time. Buenos Aires: Adriana Hidalgo Editora.

Heidegger Martin (1975). Ser y tiempo. Madrid: Editorial Trotta.

Kandinsky Wassily (1952). Punto y línea sobre el plano. Contribución al análisis de los elementos pictóricos. Barcelona: Editorial Labor.

Klee Paul (1976). Teoría del arte moderno. Buenos Aires: Ediciones Caldén.

Ollman Leah (2019). Review: David Hockney's latest: 'photographic drawings' and delectable paintings. In Los Ángeles Times <https://www.latimes.com/entertainment/arts/la-et-cm-david-hockney-review-201903|4-story.html>.

Pallasmaa Juhani (20I I). Materia, hapticidad y tiempo. In Revista el Croquis, n I 58. Madrid.

Sainz Jorge (1990). El dibujo de arquitectura. Teoría e historia de un lenguaje gráfico. Madrid: Editorial Nerea.

Smithson Alison, Smithson Peter (1992). The charged void: urbanism. New York: The Monacelli Press.

Solnit Rebecca (2004). River of Shadows: Eadweard Muybridge and the Technological Wild West. New York: Penguin Books.

Tusquets Oscar (2019). Pasando a limpio. Barcelona: Acantilado.

Wittgenstein Ludwig (1999). Investigaciones filosóficas. Barcelona: Ediciones Altaya (I Ed. 1958. Philosophische untersuchungen, London: Basil Blackwell).

\section{Author}

Pablo Jeremías Juan Gutiérrez, Universidad de Alicante, pablo.juan@gcloud.ua.es

To cite this chapter: Gutiérrez Pablo Jeremías Juan (2020). Ideas reversibles, dibujos irreversibles. El tiempo como conector, en el dibujo de arquitectura, entre la mano que dibuja y el ojo que lee/Reversible ideas, irreversible drawings. Time as a conector between the hand that draws and the eye that reads. In Arena A., Arena M., Brandolino R. G., Colistra D., Ginex G., Mediati D., Nucifora S., Raffa P. (a cura di). Connettere. Un disegno per annodare e tessere. Atti del $42^{\circ}$ Convegno Internazionale dei Docenti delle Discipline della Rappresentazione/Connecting. Drawing for weaving relationships. Proceedings of the 42th International Conference of Representation Disciplines Teachers. Milano: FrancoAngeli, pp. I 205 - I 220. 